\title{
A PRECEDENCE EVALUATION OF DEMAND AND SUPPLY BETWEEN VOCATIONAL HIGH SCHOOL GRADUATES AND WORKFORCE REQUIREMENT IN INDONESIA
}

\author{
Amat Jaedun ${ }^{1 *}$, Muhd Khaizer Omar ${ }^{2}$, Badrun Kartowagiran ${ }^{1}$, Edi Istiyono ${ }^{1}$ \\ ${ }^{1}$ Department of Educational Research and Evaluation, Universitas Negeri Yogyakarta \\ Jl. Colombo No. 1, Karangmalang, Depok, Sleman, Yogyakarta 55281, Indonesia \\ ${ }^{2}$ Department of Science and Technical Education, Universiti Putra Malaysia \\ Persiaran Masjid, Serdang, Selangor 43400, Malaysia \\ *Corresponding Author. E-mail: jaedun@uny.ac.id
}

\begin{abstract}
The success in implementing the demand-driven approach in Vocational High Schools (VHS) can be realized by understanding the misalignment between graduate skill competency and workforce demand by the industry. This study aims at describing the precedence between the VHS graduates and the businesses/industrial sector (BS/IS) portraying from the regional potential perspectives. The research data was collected from documents, and survey forms distributed to BS/IS within the research population. The document analysis was employed to collect information on programs offered at VHS, existing VHS student enrollment, and the value of Gross Regional Domestic Product (GRDP) in studied provinces. An online survey was distributed to all VHS graduates and BS/IS employers. The content validity was carried out prior actual study to ensure the validity of the instrument. A descriptive analysis was performed to gather information pertaining to developed research objectives. The precedence of the academic programs with the GRDP was determined based on $5 \%$ of criteria differences. The results found that there is a misalignment between the academic programs and the VHS student's enrollment towards the region job potentials in each province in Indonesia. In addition, the research also found that the competency of VHS graduates related to theoretical knowledge, job characteristics, and workforce skills were at a moderate level. The implication of the study offers a salient notion on minimizing the precedence that occurs between the supply and demand in the form of graduates supply to the workforce and, at the same time, fulfilling the workforce requirements demand by the industries.
\end{abstract}

Keywords: alignment, VHS study program, region potential

How to cite: Jaedun, A., Omar, M., Kartowagiran, B., \& Istiyono, E. (2020). A precedence evaluation of demand and supply between vocational high school graduates and workforce requirement in Indonesia. Jurnal Penelitian dan Evaluasi Pendidikan, 24(1), 27-38. doi:https://doi.org/10.21831/pep.v24i1.29580

\section{INTRODUCTION}

Vocational High Schools (VHS) sets a mission to produce a skilled workforce that is able to meet the employment requirements. The VHS graduates foresee the opportunity to continue their education to a higher level. They are expected to create independent businesses and venture entrepreneurship (Jaedun et al., 2017). Likewise, Rupert and Evans (n.d.), as cited in Ministry of Education and Culture (2016), stated that vocational education is one of the pillars in the national education system that prepares a person to work in certain occupations. This statement suggests that VHS graduates should have specific skills in their field of study and be competent to enter the workforce. The data from the National Statistics Bureau or Biro Pusat Statistik (BPS) in August 2019 reported that in recent years, the unemployment rate 
increased by 1000 cases, and the highest portion, about $10.42 \%$, was produced from the VHS graduates (National Statistics Bureau, 2019).

The high unemployment rate of VHS graduates indicates a significant problem in these educational institutions. The unemployment rate also depicts the mismatch between supply and demand related to quantity, quality, and precedence of the VHS graduates' expert area on meeting the Business Sector or Industrial Sector (BS/IS) workplace requirement. This mismatch refers to the quantified issue (the number of graduates produced by VHS as prospective employees exceeding the number required by BS/IS, the quality and the relevancy, the lack of workforce competency among graduates in meeting BS/IS job requirements.

This study describes the precedence of VHS graduates with the BS/IS requirements reflected upon regional potentials. Inclusively, the precedence between the number of study programs in VHS and regional potentials as well as VHS graduate competency in meeting BS/IS demands.

The VHS development in Indonesia is based on vocational education revitalization from the Presidential Instruction No. 9 of 2016. The policy report refers to an ideal approach to organize vocational education and be utilized as the foundation for prospective educational stakeholders in developing the VHS education system (Ministry of Education and Culture, 2016). The vocational revitalization mainly concerns the changes in philosophy from supplydriven to demand-driven. Besides, the implementation of a dual system is prioritized by embedding theoretical knowledge, which is learned through a conventional classroom environment to practical, real-life workplace settings.

The success of vocational education lies in graduates' capabilities in fulfilling the demand of BS/IS requirements. For ensuring the success of the vocational education implementation, it must be proven from the quality and relevancy of the academic program, an adequate number of enrollment and students graduate from the program as well as minimizing the misalignment of the workforce demands with the VHS graduate area of specializations (Sutarto, 2019, p. 24).

Regional excellence is one of the potentials in each region that can be managed and developed into products or services or works for high value, which are unique and have comparative and competitive advantages (Maknun, 2012; Prihantini, 2014). In this study, regional excellency or region potential is limited as natural and social resources existing in a certain area that has been developed into a business unit or economic value. The economic value of regional superiority can be measured based on the indicator of regional community income growth rates called Gross Regional Domestic Product (GRDP).

The GRDP refers to the number of added values generated by all business units in a certain area, or the total value of goods and final services produced by all economic units (National Statistics Bureau, 2018). The use of GRDP as the indicator of potential regional excellence is in-line with research conducted by Yunan (2011) and Safitri et al. (2012), which utilized GRDP to measure the regional potential in each province.

The disparity exists between VHS and the BS/IS based on the link and matching concept. The alignment is to bring together the supply and the demand side, including several dimensions described as to the quantity, quality, competence, location, and time. Djatmiko et al. (2013, p. 64) state that this "link and match" occurs when a school is able to produce graduates that are in line with what is needed by graduates (BI/IS).

\section{RESEARCH METHOD}

This research is an evaluation of educational planning in VHS based on the balance of supply and demand factors. The research data were collected from a number of documents and survey forms. The documents consist of the academic program name, the current number of vocational student enrolment in Indonesia, and the GRDP numerical data for the studied 
provinces. A quantitative descriptive survey study and a set of questionnaires was distributed using an online platform to VHS graduates and BS/IS employers. The questionnaire for VHS was in the form of open-ended questions to explore the efforts made by schools to align the region's potential. Meanwhile, the instrument for BS/IS was in the form of assessment sheets to assess the graduates' competency in four different aspects, i.e., theoretical knowledge, digital literacy, data literacy, and humanity literacy. The data from the online survey was gathered from 699 VHS nationwide and four BS/IS employers.

The respondents of this study were the principals, the teachers, the students of VHS, and the employers among BS/IS. The number of respondents who participated in the online survey is presented in Table 1.

Table 1. The Number of Respondents

\begin{tabular}{lcc}
\hline No & Role of respondent & Frequency (n) \\
\hline 1 & Principal & 699 \\
2 & Teacher & 4,690 \\
3 & Student & 15,853 \\
4 & BS/IS & 4 \\
& Total & $\mathbf{2 1 , 2 4 6}$ \\
\hline
\end{tabular}

The instrumentation for data collection consisted of a set of questionnaires and a document list. The validation was warranted from the content validity procedure. The data analysis technique was a quantitative descriptive analysis. The quantitative descriptive findings were employed to conduct comparative analysis on the number of academic programs and student enrollment in each province towards the GRDP values. The VHS graduates' competency data was gathered based on BS/IS employer assessment. The alignment criteria for the study programs and the VHS student number towards the GRDP was based on the difference criterion of $\leq 5 \%$. On the other hand, the study program and the GRDP with a percentage of below $5 \%$ were excluded from the analysis procedure due it was not considered to be the region's potentials factor.

\section{FINDINGS AND DISCUSSION}

\section{Quantitative Alignment}

Table 2 presents the GRDP percentage, the list of the academic program, and the number of VHS students in Indonesia within five areas of specialization, i.e., the academic programs with the GRDP potential of more than $5 \%$.

Table 2. The Quantitative Alignment of VHS with the Regional Excellence in Five Areas of Specializations

\begin{tabular}{|c|c|c|c|c|}
\hline No & Area of specialization & $\begin{array}{c}\text { Range of } \\
\text { GRDP Value } \\
(\%)\end{array}$ & $\begin{array}{c}\text { Range of } \\
\text { Expertise Field } \\
(\%) \\
\end{array}$ & $\begin{array}{c}\text { Range of } \\
\text { Students } \\
\text { Number (\%) }\end{array}$ \\
\hline 1. & Technology and Engineering & $21.0-68.0$ & $14.66-38.17$ & $8.82-46.67$ \\
\hline 2. & Business and management & $0.99-31.24$ & $4.45-58.37$ & $8.30-54.58$ \\
\hline 3. & Information and Communication Technology & $0.93-15.63$ & $8.56-33.62$ & $7.37-28.01$ \\
\hline 4. & Agribusiness \& Agrotechnology & $0.0-34.98$ & $0.16-28.64$ & $0.16-23.17$ \\
\hline 5. & Tourism & $3.15-29.60$ & $3.52-41.19$ & $3.09-59.49$ \\
\hline
\end{tabular}

The 2018 GRDP data (National Statistics Bureau, 2018) illustrated a similar trend in almost all provinces in Indonesia (except Bangka Belitung, East Kalimantan, and Riau), where the economic potential was dominated by the jobs in the Technology and Engineering field 
with the percentage of the GRDP rupiah value ranging from $21 \%$ to $68 \%$. Similarly, it is approximately all provinces (except Bali, Jakarta, and South Sumatra), among the VHS expert areas, was also dominated by the field of Technology and Engineering from 15\% to 39\%. These findings corroborated with the 2018 vocational skills spectrum (Regulation of the Director General of Primary and Secondary Education, Ministry of Education and Culture No. 66/D.D5/KK/2018) that VHS in the field of technology and engineering has the most study programs, with 13 study programs and 58 specialized competencies, and possess the highest number of students enrollment. However, the potential employment available for vocational graduates of technology and engineering expertise was still far beyond the graduates' number. Quantitatively speaking, the VHS of technology and engineering expertise is not suitable for available employment opportunities.

Moreover, such needs to be observed was the high percentage of GRDP achieved in the field of technology and engineering was generally caused by its employment characteristics, which contributed to high economic value for capital and technology intensity; however, this was not constantly accompanied by high demand of the VHS graduates. For example, the manufacturing industries are more likely to reduce vocational graduates' employment intake since they have utilized the automation system. In all provinces in Indonesia, the automotive engineering academic program has become the dominant program in the field of technology and engineering. At the same time, the VHS employment data in the National Labor Force Survey in 2018 (National Statistics Bureau, 2018) showed that the employment rate of VHS graduates of the automotive engineering program was the lowest. In other words, the graduates of this academic program became the highest contributors to the unemployment rate, with 356,081 unemployed graduates compared to other academic programs.

The data of VHS expertise programs in most provinces (except West Nusa Tenggara) demonstrated that the area of business and management expertise possessed a considerable number of areas of specialization with the range of $10 \%$ to $58 \%$. The students' numbers shared a similar range. However, the GRDP data showed that the employment potential available for graduates in the Business and Management program was significantly low, around 5\% (the lowest was in Riau with $0.99 \%$, and North Kalimantan with $1.50 \%$ ). The data indicated that the VHS in Business and Management program in most of the provinces was not synchronized with the available job market. The implication of this circumstance proved that most VHS graduates in business and management expertise more likely to be excluded from job placement. As such, they will be unemployed or work in areas that are irrelevant within their specialization. The data were supported with the vocational employment data (National Statistics Bureau, 2018), which indicated that the unemployment rate of VHS graduates in the business and management field was relatively high at 333,017, whereas 180,904 from the office administration program and 152,113 from the finance program.

The data of VHS study programs in most of the provinces also showed the domination of the Information and Communication Technology (ICT) field. The number of study programs in ICT ranged from $10 \%$ to $30 \%$, with the number of students, about $20 \%$ to $25 \%$ (except Bangka Belitung with 7.37\%). On the other hand, the available employment potential according to the 2018 GRDP was low with an average below 5\% (the lowest was in Riau with $0.93 \%$; North Sulawesi with 1.04\%; and $1.13 \%$ for Central Kalimantan). This data indicated that the VHS of the ICT area was not aligned with the available job market in most provinces. It is implied that many VHS graduates of ICT expertise will not be accommodated by available employment; hence they will be either unemployed or work beyond their area of specialization. Notably, the data from the National Labor Force in 2018 proved that the number of unemployed VHS graduates in the field of ICT was relatively high, at 228,554 graduates.

In 2018, GRDP data depicted that agribusiness and the agro-technology placed the least number from the listed skill programs. Jakarta with $0.0 \%$ and Riau Islands with $1.44 \%$ were found the lowest of all studied provinces, while among the highest was in Aceh with $28.80 \%$, 
followed by East Nusa Tenggara and North Sulawesi with $28.88 \%$ and $34.98 \%$ respectively. It was found that a smaller percentage of students compared to the number of available skills programs. Meanwhile, the employment potential available in most of the provinces (except Jakarta) was much higher than the number of graduates. This data illustrated that the field of agribusiness and agro-technology in most of the provinces was not suitable for the availability of the current job market. However, all VHS graduates in this field will be accommodated by the available employments. An interesting fact in the agribusiness and vocational expertise was that the percentage of the available study programs was higher than the percentage of students in the expertise program. It is indicated that the agribusiness and agro-technology program was less attractive to prospective students. For this reason, the Director of Vocational High School Administration needs to encourage the Agribusiness and Agrotechnology programs to enhance their capacity since the available job markets still have the large opportunity to absorb the graduates.

Another point of the 2018 GRDP data was that VHS in the tourism field with a varied number of academic programs. The lowest was reported in the province of Bangka Belitung with $3.15 \%$, and the highest was in Bali with $29.60 \%$. The percentage of the students' number in Bali was much higher, with $59.60 \%$, than the number of vocational students in this province. The available employment potential was also quite varied, some were higher than the number of graduates, and some others were lower. The research showed that the employment opportunities for tourism graduates in various regions were different. The lowest employment opportunities for the tourism field were in the province of North Sulawesi, with $0.47 \%$ and $11.12 \%$ for the total number of VHS graduates in this province. Meanwhile, the highest employment opportunities for vocational graduates in the tourism field were in the province of Bali with a percentage of $29.60 \%$, but the graduates in this field far exceeded the available employment opportunities of $59.60 \%$. The data indicated that in the provinces of North Sulawesi and Bali, the number of VHS graduates of tourism was too many than the available employment. Thus, many tourism graduates from the two provinces would not be accommodated by available employment. They might as well become unemployed or work beyond their area of specialization. In most provinces (except Bali), the low employment opportunities of VHS graduates in the field of tourism were more likely because of the slow progress in the tourism industry in each region, which supposedly would increase the GRDP and create more job opportunities for VHS graduates in tourism academic program.

The analysis results on the alignment of the expertise field and the number of vocational students towards the region potential reflected by the value of the GRDP can be suggested as follows.

First, the study program held in VHS in most of the provinces in Indonesia (except Bali) was dominated by three academic programs: automotive engineering (technology and engineering field), informatics \& computer engineering (informatics \& computer engineering field), and business and management (financial or accounting, marketing management, and office administration). Meanwhile, the existence of other study programs was very small, with an average below 5\%. The data indicated highly imbalanced in the distribution of vocational study programs.

The findings reinforce the presumption that the development of VHS is still strongly influenced by the public interests in which the opening of a certain academic program refers to the trend which is demanded by the prospective students. It contributes to a wide disparity in the number of VHS graduates and the employment rate in certain areas. As a result, the number of unemployment among VHS graduates occupy the highest ranking compared to other education levels. It also causes the region's slow development due to the absence of skilled workers to build the area based on the region's potential of the region (Mukhadis et al., 2017). 
Secondly, the data on the vocational graduates (National Statistics Bureau, 2018) found that the five vocational academic programs that contributed to the most unemployment in 2018 were automotive engineering, mechanical engineering, informatics and communication technology (ICT), office administration, and also finance. The automotive engineering study program contributed to the largest portion of 356,081 people. In order to make it clearer, a diagram is presented in Figure 1.

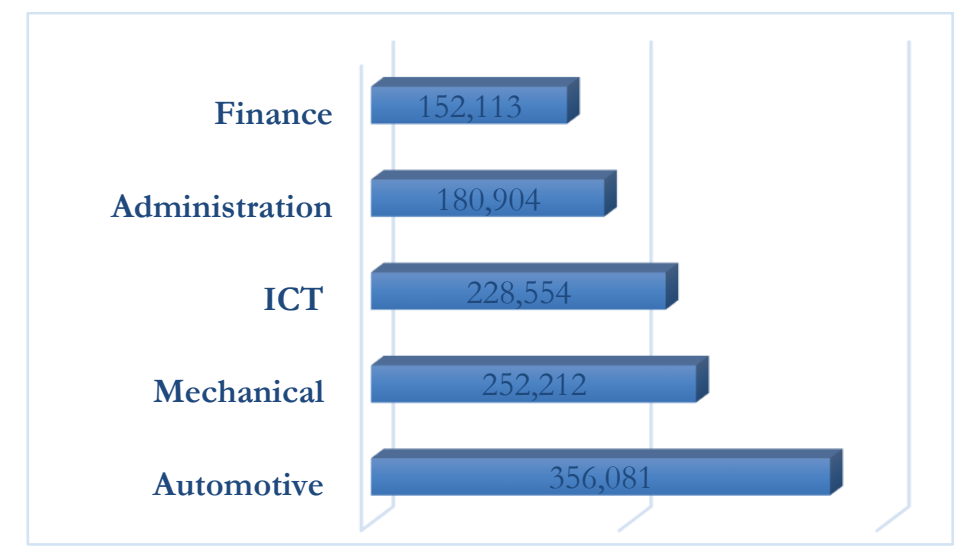

Figure 1. The VHS Study Program as the Highest Unemployment Rate (National Statistics Bureau, 2018)

This finding is crucial to be observed because the high unemployment rate of the VHS graduates can be interpreted positively as a high public interest in the study program. On the contrary, it can also indicate a mismatch between supply and demand in the study programs. In this case, the graduates' absorption is mainly due to the quantity problems, i.e., the number of prospective vocational school graduates that exceeds the workforce that is required by the BS/IS.

There is a mismatch between the number of VHS graduates (seen from the percentage of students' number of certain academic programs) and the region potential. It urges not only the need for a wide job market to accommodate the unemployed VHS graduates but also the irrelevancy between the VHS study program and the region potential that results in the ineffective management of the region's potential due to the lack of skilled human resources.

\section{Qualitative Alignment}

The alignment of graduate quality with the BS/IS requirements can be measured based on three aspects, i.e., knowledge competency, work character, and technical skills. Jaedun and Slamet (2019) listed work abilities into three categories: (a) personal quality (character), (b) knowledge competence (core skill), and (c) technical skill.

\section{Knowledge Competency}

The knowledge competency of VHS graduates is assessed based on four aspects, namely theoretical knowledge, digital literacy, data literacy, and also humanity literacy. The results of the BS/IS assessment on the knowledge competency of the VHS graduates showed that, as a whole, it was in the adequate category. However, for the theoretical knowledge aspect, it was considered "poor". As many as 50\% of BS/IS stated that the theoretical knowledge of VHS graduates was "poor", 25\% was "moderate", and 25\% was "good". Meanwhile, for the other three aspects, at least $50 \%$ of BS/IS mentioned that the aspects of digital literacy, data literacy, and also humanity literacy of VHS graduates were adequate. The results of the competency assessment among VHS graduates' knowledge by BS/IS are presented in Table 3. 
Table 3. Knowledge Assessment on VHS Graduates

\begin{tabular}{lcccc}
\hline \multirow{2}{*}{ Assessment Aspects } & \multicolumn{4}{c}{ Assessment of BS/IS (\%) } \\
\cline { 2 - 5 } & E & G & M & P \\
\hline Theoretical Knowledge & 0 & 25 & 25 & 50 \\
Digital literacy & 0 & 25 & 50 & 25 \\
Data Literacy & 0 & 25 & 75 & 0 \\
Humanity Literacy & 0 & 50 & 50 & 0 \\
\hline
\end{tabular}

Annotation: E (Excellent), G (Good), Moderate (M), Poor (P)

The assessment of theoretical knowledge among VHS graduates was to fulfill the demands of the 21 st century and the Industrial Revolution 4.0 era, in which the workforce must have the appropriate competencies, such as, the latest knowledge, attitudes, and also the proper ability to perform the work based on the job requirement (Oviawe et al., 2017). It is also in line with the idea of Flynn et al. (2016) that certain jobs in the Industrial Revolution 4.0 era require a competent workforce with specific knowledge, skills, and also contextual understanding.

\section{The Character of VHS Graduates}

The alignment of work character among VHS graduates with the needs of the BS/IS was assessed based on five aspects, such as discipline, responsibility, honesty, ethics or morals, and self-confidence, as presented in Table 4. The working character was categorized on four criteria: Excellent (E), Good (G), Moderate (M), and Poor (P).

Table 4. Assessment on Work Character among VHS Graduates According to BS/IS

\begin{tabular}{lcccc}
\hline \multirow{2}{*}{ Character Aspect } & \multicolumn{4}{c}{ BS/IS Assessment (\%) } \\
\cline { 2 - 4 } & E & G & M & P \\
\hline Discipline & 0 & 25 & 75 & 0 \\
Responsibility & 0 & 25 & 75 & 0 \\
Honesty & 0 & 25 & 75 & 0 \\
Ethics / Moral & 0 & 50 & 50 & 0 \\
Self-Confidence & 0 & 25 & 75 & 0 \\
\hline
\end{tabular}

Annotation: Excellent (E), G (Good), Moderate (M), Poor (P)

The working character among VHS graduates as a whole can be categorized as "moderate" in which $75 \%$ of the BS/IS reported that the graduates possess required work characters such as discipline, responsibility, honesty, and confidence. In the ethics or moral traits, $50 \%$ of the BS/IS reported that VHS graduates possess good ethical values, and another $50 \%$ placed at a moderate level. None of the BS/IS mentioned that the work character among VHS was "poor". It is a vital fact that possession of positive job characteristics is a fundamental and crucial aspect of the current workforce. It is advisable that the job characteristics be nurtured as early as school level by emphasizing the soft skills elements. Hidayat et al. (2019) stated that it is important to instill the soft skills values which includes communication, honesty, discipline, self-awareness, motivation, teamwork, leadership, adaptation, and problem-solving. On the other hand, soft skills or employability skills should be emphasized at different educational levels, especially at the training institutions to accelerate graduates and school leavers employed by the industrial players (Omar et al., 2012).

\section{VHS Graduates’ Workforce Skills}

The alignment of vocational graduates' skills with the needs of BS/IS was assessed based on five aspects, namely technical ability, accuracy, collaboration, creativity, and productivity. It is presented in Table 5. 
34 - Amat Jaedun, Muhd Khaizer Omar, Badrun Kartowagiran, \& Edi Istiyono

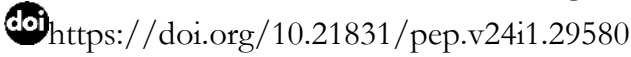

Table 5. Assessment on VHS Graduates' Skills According to BS/IS

\begin{tabular}{lcccc}
\hline \multirow{2}{*}{ Work Skills Aspect } & \multicolumn{4}{c}{ BS/IS Assessment (\%) } \\
\cline { 2 - 5 } \multicolumn{1}{c}{ E } & G & M & P \\
\hline Technical Skills & 0 & 25 & 75 & 0 \\
Accuracy & 0 & 25 & 50 & 25 \\
Cooperation & 0 & 25 & 75 & 0 \\
Creativity & 0 & 0 & 75 & 25 \\
Productivity & 25 & 0 & 75 & 0 \\
\hline
\end{tabular}

Annotation: E (Excellent), G (Good), Moderate (M), Poor (P)

The VHS graduates' workforce skills were found at a moderate level, with $75 \%$ of the BS/IS reported that the graduates possessed adequate skills in the aspects of technical ability, collaboration, creativity, and productivity. Meanwhile, $25 \%$ of BS/IS indicated that VHS graduates possessed good practical and also collaborative skills. In addition, $25 \%$ of the BS/IS described that VHS graduates possessed a poor level of accuracy and creativity elements.

In addition, the BS/IS also suggested that VHS graduates should improve their language ability and negotiation skills. This is consistent with research by Hidayat et al. (2019), which states that VHS graduates need to have certified supporting competencies that include computer skills, language skills (English and Mandarin), and other aspects of soft skills. The aforementioned skills can be practiced via informal and formal learning environments as those skills are related to day-to-day matters, for instance, having a conversation with different people and dealing with assignments (Omar et al., 2012).

\section{The Precedence of VHS with Local Potential}

The findings indicated that there had been a mismatch between the number of study programs as well as the number of graduates produced by VHS and the needs of the workforce in the BS/IS. This inconsistency quantitatively was also getting worse due to the discrepancies of the quality aspect. Therefore, the VHS study programs' alignment pattern to the region potential that was reflected by the needs of the workforce should be made through two models, namely quantitative and quality aspects.

The mismatch between the VHS programs and BS/IS job requirement aspects can be aligned by the Director of VHS and the Provincial Education Office by making sure the supply meeting the demand. This authority has been supported by the Regulation of the Minister of Education and Culture No. 36 of 2014 concerning the guidelines for the establishment, amendment, and closing of primary and secondary education units, article 5 especially points (b), and (c) which states that the Director of VHS and the Provincial Education Office have the authority to reduce (partial closing) the vocational study programs that are considered over-supply, and not supported the region potential, and low employment opportunities. Emphasizes on the opening of new programs shall take place to synchronize industrial demands hence optimize regional potentials.

Meanwhile, the quality aspect of graduates' workforce skills is significant, and prioritization should take place in educational institutions to enhance graduate's quality in terms of competencies and possession of skills. This is in line with the VHS development policy in the Presidential Instruction No. 9 of 2016 stated that the basic concept of education revitalization in VHS is to change the philosophy from supply-driven to demand-driven which is operationally done by strengthening cooperation between VHS and BS/IS to gradually build the consistency between the graduates' competence and the BS/IS needs.

The BS/IS involvement is primarily aimed at improving the quality and relevance of vocational graduates by improving the quality of vocational teaching and learning approaches. Few actions can take place by the vocational education stakeholders to improve the imple- 
mentation. First, curriculum development and the alignment with the demands of BS/IS. Secondly, engaging BS/IS to provide training for vocational teachers to keep them updated with new knowledge and skills related to current technological developments within their specialization. Next, by requesting the BS/IS to send their professional staff as accompanying teachers or mentors for students. On top of that, by inviting BS/IS for educational funding in building laboratories, workshops or practical facilities and equipment. To add with, by optimizing the role of BS/IS in providing industrial practice for VHS students and internship program to broaden their insights about the workplace; and finally, boosting the role of BS/IS in improving the quality of teaching and learning and the development of teaching factory.

The following factors are important in improving the quality of vocational graduates from the educational institution. Most importantly, the curriculum must be aligned with industry requirements, and the teaching and learning quality must be taken seriously and meet the academic standard.

\section{VHS Curriculum Alignment}

The most urgent step to implement is a dual system education model to ensure the synchronization of the VHS curriculum and industrial demands. In this case, the curriculum needs to be adjusted periodically by involving graduate users. The curriculum alignment functions to bring together the supply side and the demand side, which includes several dimensions, i.e., the quantity, the quality, and the relevance.

\section{Enhancing the Learning Quality}

The effort to align VHS with BS/IS is to introduce a model of teaching and training in BS/IS to be implemented in the schools. It includes the application of work-based learning, production-based learning, and experiential learning via a real-life industrial environment.

Work-based learning (WBL) refers to learning through the workplace, both work experience and job shadowing at a certain time. Another understanding states that the WBL or work-integrated learning (WIL) was a learning approach that utilizes the workplace to structure experiences gained in the workplace that contribute to the social, academic, and career development among students and become the supplement of learning activities (Siswanto, 2011; Tran, 2015).

Meanwhile, Production-based Learning (PbL) means a learning model that is designed to improve the competency of VHS students in producing products through work processes in the workplace. In this case, $\mathrm{PbL}$ is a learning procedure or step to facilitate students for active learning, participation, and interaction to achieve competence of product development, either goods or services needed by the community (Ganefri, 2013).

Experiential learning via a real-life industrial environment refers to an industrial project that aims to provide real experience in product design, manufacturing, and realization. This method integrates two main environments, that are, the school and the workforce. This learning will allow students to acquire skills, experience, and attitudes based on the applicable standards in the BS/IS.

Those alignment efforts can run optimally with several conditions as follows. It must have good planning, consistent, full commitment, adequate facilities from the VHS directors, and full support from the local government and other relevant bodies. Another determining factor is the existence of government policies and supporting law. In this case, the government has issued regulations regarding the calculation of taxable income and the payment of income tax in the current year of which the government provides tax reduction incentives to companies with the following conditions (Government Regulation No. 45 of 2019, article 29B). 
Paragraph (1) in that particular policy report mentions that domestic taxpayers who provide work practices, internships, and/or learning activities in the framework of competencybased human resources development can obtain a gross income tax reduction of at most $200 \%$ of the total costs incurred for those activities. In addition, paragraph (2) confirms that certain competencies as referred to in paragraph (1) are to improve the quality of the workforce through work practices, internship programs, and/or strategic learning activities to achieve the effectiveness and efficiency of labor as part of human resource investment, and meet the structure of the workforce according to the needs of the business sector and/or the industrial sector.

\section{CONCLUSION}

Two conclusions were drawn upon the results and discussion section. First, precedence occurs between academic programs and the number of students enrolled in vocational schools towards the region potential based on GRDP in each province in Indonesia. Secondly, the ability of VHS graduates related to their theoretical knowledge, work character, and skills according to the BS/IS assessment reported at a moderate level cumulatively. Future study on understanding the academic program preparedness in meeting the rapid evolvement of the Industrial Revolution (IR 4.0) is suggested. In general, the expansion of IR 4.0 has changed the educational landscape in Indonesia.

\section{REFERENCES}

Directorate General of Primary and Secondary Education. (2018). Regulation of the Director General of Primary and Secondary Education, Ministry of Education and Culture No. 66/D.D5/ KK/2018, on the Expertise Spectrum of Vocational Secondary School (VHS)/Vocational Madrasah Aliyah (VMA). Directorate General of Primary and Secondary Education.

Djatmiko, I. W., Siswanto, B. T., Sudira, P., Hamidah, H., \& Widarto, W. (2013). Modul pendidikan teknologi dan kejuruan (I. W. Djatmiko (ed.)). Fakultas Teknik Universitas Negeri Yogyakarta. http://staffnew.uny.ac.id/upload/131629061/pendidikan/bahanajar-pendidikan-teknologi-kejuruan-2013.pdf

Flynn, M. C., Pillay, H., \& Watters, J. (2016). Industry-school partnerships: Boundary crossing to enable school to work transitions. Journal of Education and Work, 29(3), 309-331. https://doi.org/10.1080/13639080.2014.934789

Ganefri, G. (2013). The development of production-based learning approach to entrepreneurial spirit for engineering students. Asian Social Science, 9(12), 162-167. https://doi.org/10.5539/ass.v9n12p162

Government Regulation No. 45 of 2019 on the Alteration of the Government Regulation No. 94 of 2010 on the Calculation of Taxable Income and Income Tax Settlement in the Year-to-Date, (2019).

Hidayat, R., Vicihayu, D. M., \& Ulya, H. (2019). Kompetensi kepala sekolah abad 21: Sebuah tinjauan teoretis. Jurnal Kepemimpinan Dan Pengurusan Sekolah, 4(1), 61-68. https://doi. org/10.34125/kp.v4i1.394

Jaedun, A., Hariyanto, V. L., \& Raharjo, N. E. (2017). Developing an entrepreneurship-loaded productive learning model. Jurnal Kependidikan: Penelitian Inovasi Pembelajaran, 1(1), 125138. https://doi.org/10.21831/jk.v1i1.10520 
Jaedun, A., \& Slamet, S. (2019). Kompetensi lulusan SMK Teknologi Konstruksi dan Properti yang dibutubkan industri jasa konstruksi di D.I. Yogyakarta. Fakultas Teknik Universitas Negeri Yogyakarta.

Maknun, D. (2012). Pengembangan sekolah menengah kejuruan (SMK) boarding school berbasis keunggulan lokal. http://file.upi.edu/Direktori/FPTK/JUR._PEND._TEKNIK_ARSI TEKTUR/196803081993031-JOHAR_MAKNUN/smk-boarding-school.pdf

Ministry of Education and Culture. (2016). Konsep pembelajaran di Sekolah Menengah Kejuruan. Directorate of Vocational High School, Ministry of Education and Culture. http://smk. kemdikbud.go.id/konten/1869/konsep-pembelajaran-di-sekolah-menengah-kejuruan

Mukhadis, A., Putra, A. B. N. R., Nidhom, A. M., Dardiri, A., \& Suswanto, H. (2017). Panduan sinkronisasi bidang keablian di SMK dengan prioritas potensi unggulan wilayah dan tenaga kerja (T. Haryani, Y. Setiawan, \& M. Herdyka (eds.)). Directorate of Vocational Secondary School, Ministry of Education and Culture.

National Statistics Bureau. (2018). Keadaan angkatan kerja di Indonesia Agustus 2018: Hasil sensus angkatan kerja nasional (Sakernas) Agustus 2018. National Statistics Bureau - Statistik Indonesia.

National Statistics Bureau. (2019). Keadaan angkatan kerja di Indonesia Agustus 2019: Hasil sensus angkatan kerja nasional (Sakernas) Agustus 2019. National Statistics Bureau - Statistik Indonesia.

Omar, M. K., Bakar, A. R., \& Rashid, A. M. (2012). Employability skill acquisition among Malaysian community college students. Journal of Social Sciences, 8(3), 472-478. https:// doi.org/10.3844/jssp.2012.472.478

Oviawe, J. I., Uwameiye, R., \& Uddin, P. S. O. (2017). Bridging skill gap to meet Technical, Vocational Education and Training school-workplace collaboration in the 21st Century. International Journal of Vocational Education and Training Research, 3(1), 7-14. https://doi. org/10.11648/j.ijvetr.20170301.12

Presidential Instruction No. 9 of 2016 on the Revitalization of Vocational Secondary School, (2016).

Prihantini, P. (2014). Pengembangan kurikulum Pendidikan Berbasis Keunggulan Lokal (PBKL) (Studi deskriptif evaluatif pada dua SMA penyelenggara PBKL, di Kabupaten Sukabumi dan Kota Bogor) [Doctoral dissertation. Universitas Pendidikan Indonesia]. http://repository.upi.edu/ 12038/1/D_PK_0908816_Title.pdf

Regulation of the Minister of Education and Culture No. 36 of 2014 on the Guidelines for the Establishment, Amendment, and Closing of Primary and Secondary Educational Units, (2014).

Safitri, B. R. A., Syafrudie, H. A., \& Sutrisno, S. (2012). Relevansi program studi keahlian Teknik Bangunan dengan pekerjaan lulusan. Teknologi Dan Kejuruan: Jurnal Teknologi, Kejuruan Dan Pengajarannya, 35(1), 29-36. https://doi.org/10.17977/tk.v35i1.3713

Siswanto, B. T. (2011). Pendidikan vokasi, work-based learning, dan penyelenggaraan program praktik pengalaman lapangan. Paper Presented at Workshop Penyusunan Buku Panduan Penulisan Laporan KP, TA, Skripsi Fakultas Teknik Universitas Mubammadiyah Magelang. http://staff.uny.ac.id/sites/default/files/tmp/Makalah Ceramah UMM 2011.pdf

Sutarto, S. (2019). Filosofi dan pengembangan kurikulum pendidikan vokasi dalam era disrupsi. Innauguration Scpeech of Professor of Universitas Negeri Yogyakarta. 
Tran, T. T. (2015). Is graduate employability the 'whole-of-higher-education-issue'? Journal of Education and Work, 28(3), 207-227. https://doi.org/10.1080/13639080.2014.900167

Yunan, Z. Y. (2011). Analisis sektor unggulan Kota Bandar Lampung (Sebuah pendekatan sektor pembentuk PDRB). Proceeding of Seminas Competitive Advantage I. http://journal. unipdu.ac.id:8080/index.php/seminas/article/view/41 